\title{
Analisa Komposisi Bahan Penyusun Kertas Medium Fluting, Brown Kraft, dan Test Liner
}

\author{
Andhika Dwi Anggoro', Fatkur Rhohman ${ }^{2)}$ \\ 1)2) Program Studi Teknik Mesin, Universitas Nusantara PGRI Kediri \\ E-mail: ${ }^{1)}$ andhika.anggoro.22@gmail.com, ${ }^{2}$ fatkurrohman@unpkediri.ac.id.
}

\begin{abstract}
Abstrak
Kertas merupakan bahan tipis yang dibuat dari serat-serat nabati pendek yang diendapkan serta dikeringkan. Serat yang digunakan umumnya merupakan natural, serta memiliki selulosa serta hemiselulosa. Kertas dalam bahasa inggris diucapkan paper serta dalam bahasa belanda papier. Kertas merupakan benda lembaran yang dibuat dari bubur rumput, jerami, kayu dan sebagainya, yang bisa dirobek, digulung, dilipat, direkat, dicoret mempunyai sifat yang berbeda dari bahan bakunya. Bahan baku merupakan bahan utama pembuatan kertas. Bahan baku diubah hingga menjadi barang baru yang mempunyai wujud dan sifat berlainan dari bahan asalnya. Bahan pembantu merupakan bahan-bahan yang dibutuhkan untuk memperlancar pembuatan kertas. Bahan pelengkap merupakan bahan-bahan yang dibutuhkan dalam proses pembuatan kertas supaya mendapatkan hasil yang baik tanpa bahan pelengkap kertas yang dihasilkan banyak mengandung cacat dan tidak sempurna. Bahan baku yang dipakai dalam pembuatan kertas adalah waste paper atau kertas hasil daur ulang dari kertas bekas.
\end{abstract}

Kata Kunci: bahan baku, kertas, limbah, serat.

\begin{abstract}
Paper is a thin material made from short vegetable fibers that are deposited and dried. The fibers used are generally natural, and contain cellulose and hemicellulose. Paper in English is pronounced paper as well as in Dutch papier. Paper is a sheet object made from grass pulp, straw, wood and so on, which can be torn, rolled, folded, glued, and crossed out having different properties from the raw material. Raw materials are the main ingredients for making paper. Raw materials are converted into new goods that have different shapes and properties from the original material. Auxiliary materials are materials needed to facilitate the manufacture of paper. Complementary materials are materials needed in the paper-making process in order to get good results without complementary materials, the resulting paper contains many defects and is not perfect. The raw material used in making paper is waste paper or recycled paper from used paper.
\end{abstract}

Keywords: raw materials, paper, waste, fiber.

\section{PENDAHULUAN}

Kertas merupakan bahan tipis yang dibuat dari serat-serat nabati pendek yang diendapkan serta dikeringkan. Umumnya dicampur dengan bahan-bahan tambahan 
lain dan atau bahan pewarna. Serat yang digunakan umumnya merupakan alami, serta memiliki selulosa dan hemiselulosa. Selulosa $\left(\mathrm{C}_{6} \mathrm{H}_{10} \mathrm{O}_{6}\right)$ merupakan polimer dari glukosa yang dihubungkan dengan ikatan $\beta$-1,4-glikosidik. Struktur primer rantai selulosa saling berikat satu dengan yang lainnya membentuk struktur kristalin yang disebut dengan serat mikrofibril. Serat mikrofibril berdiameter antara 2-20 $\mathrm{nm}$, tersusun atas 2000 molekul monomer, dan memiliki panjang 100-40000 nm. Serat mikrofibril ini bergabung membentuk fibril, dan gabungan fibril membentuk serat-serat selulosa. Selulosa tidak larut dalam kebanyakan pelarut [1]. Industri kertas ialah salah satu tipe industri terbanyak didunia dengan menghasilkan 178 juta ton of pulp, 278 juta ton kertas dan karton, serta menghabiskan 670 juta ton kayu. Pertumbuhan dalam dekade selanjutnya diperkirakan antara $2 \%$ sampai 3,5\% per tahun, sehingga memerlukan peningkatan kayu log yang dihasilkan dari lahan hutan seluas 1 hingga 2 juta hektar per tahun [2]. Untuk itu pemerintah memikirkan gimana dapat mengurangi beban konsumsi kayu dari hutan. Sehingga terciptalah sesuatu teknologi pembuatan kertas dengan menggunakan limbah kertas serta kardus sisa. Perkembangan industri kertas dalam beberapa tahun terakhir mengalami pergeseran dikarenakan pesatnya perkembangan teknologi informasi yang berdampak pada menurunnya penggunaan kertas sebagai media tulis-cetak.

Berdasarkan data RISI Atau Resource Information Systems Inc. pada tahun 2013 dan 2014 terjadi penurunan produksi dan konsumsi kertas budaya yaitu dalam hal ini adalah kertas koran dan kertas tulis-cetak (Tabel 1) [3].

Tabel 1. Pertumbuhan produksi dan konsumsi kertas dunia (\%)

\begin{tabular}{|l|l|l|l|l|}
\hline \multirow{2}{*}{ Jenis kertas } & \multicolumn{2}{|c|}{ produksi } & \multicolumn{2}{c|}{ konsumsi } \\
\cline { 2 - 5 } & 2013 & 2014 & 2013 & 2014 \\
\hline Total & 0.8 & 1,0 & 0,9 & 0,7 \\
\hline Kertas budaya & \multicolumn{5}{|l}{} \\
\hline -kertas koran & $-4,9$ & $-6,4$ & $-4,8$ & -7.4 \\
\hline -kertas tulis-cetak & $-1,4$ & $-1,6$ & $-1,1$ & $-1,5$ \\
\hline Kertas industri & & & \\
\hline -kertas/ karton kemasan & 2,4 & 2,8 & 2,4 & 2,8 \\
\hline Kertas housesold & & \multicolumn{5}{|l}{} \\
\hline
\end{tabular}




\begin{tabular}{|l|l|l|l|l|}
\hline- Kertas tisu & 3,6 & 3,2 & 3,3 & 3,2 \\
\hline Kertas lainnya & $-0,3$ & 1,7 & $-0,2$ & 0,6 \\
\hline
\end{tabular}

Sumber : [3]

Tabel 2. Pertumbuhan produksi dan konsumsi kertas indonesia (\%)

\begin{tabular}{|l|l|l|l|l|}
\hline \multirow{2}{*}{ Jenis kertas } & \multicolumn{2}{c|}{ produksi } & \multicolumn{2}{c|}{ konsumsi } \\
\cline { 2 - 5 } & 2013 & 2014 & 2013 & 2014 \\
\hline Total & 2,6 & 3,4 & & 3,5 \\
\hline Kertas budaya & \multicolumn{4}{|c|}{} \\
\hline -kertas koran & 0,4 & $-7,8$ & & $-10,4$ \\
\hline -kertas tulis-cetak & $-1,5$ & 2,9 & & $-5,1$ \\
\hline Kertas industri & \multicolumn{5}{|l}{} \\
\hline -kertas/ karton kemasan & 6,1 & 3,8 & 3,2 & 2,7 \\
\hline Kertas housesold & \multicolumn{5}{|l}{} \\
\hline -Kertas tisu & 7,3 & 10,2 & 7,4 & 27,1 \\
\hline Kertas lainnya & 10,3 & 13,7 & 5,0 & 2,7 \\
\hline
\end{tabular}

Sumber : [3]

Menurut RISI tahun 2016, produksi serat daur ulang indonesia tahun 2013 dan 2014 mengalami peningkatan berturut-turut sebesar $14,0 \%$ dan 5,4\% sedangkan konsumsinya juga mengalami peningkatan yaitu sebesar $6,9 \%$ dan $4,7 \%$. Hal ini menunjukan meningkatnya penggunaan serat daur ulang sebagai bahan baku kertas [3].

\section{METODE PENELITIAN}

Penelitian ini menggunaka metode kuanlitatif yaitu data data yang diperoleh dari sampel dan populasi dalam penelitian, kemudian dianalisis dengan metode deskriptif. Populasi dalam penelitian ini adalah semua data yang tersedia untuk PT.X dan sampel pada penelitian ini adalah data produksi tahun 2021. Pengumpulan data berasal dari wawancara, observasi dan dokumentasi. Pada bagian ini, data jumlah produksi digunakan sebagai sampel penelitian. Lokasi penelitian dipilih di kabupaten pasuruan yang kebetulan berada di kecamatan beji. 


\section{HASIL DAN PEMBAHASAN}

Kertas dalam bahasa inggris disebut paper serta dalam bahasa belanda disebut papier. Kertas merupakan lembaran yang dibuat dari bubur rumput, jerami, kayu dan sebagainya, yang bisa dirobek, digulung, dilipat, direkat, dicoret memiliki sifat yang berbeda dari bahan bakunya : tumbuh-tumbuhan. Kertas dibuat untuk memenuhi kebutuhan hidup yang sangat bermacam-macam.

Komponen-komponen utama dalam pembuatan kertas antara lain:

\section{a. Selulosa}

Merupakan senyawa yang terletak pada dinding sel tumbuhan terutama pada tangkai, batang, dahan, dan semua bagian berkayu dari jaringan tumbuhan. Selulosa merupakan polisakarida struktural yang berfungsi untuk memberikan perlindungan, bentuk, dan penyangga terhadap sel, dan jaringan [4]. Selulosa berfungsi sebagai penguat pada tumbuhan, lignin untuk melindungi selulosa dari aksi kimia maupun biologis sedangkan hemiselulosa pengikat selulosa dengan lignin [5].

\section{b. Hemiselulosa}

Hemiselulosa adalah polimer dengan rantai relative lebih pendek dan bercabang, terdiri dari monomer-monomer seperti xilosa, arabinosa, glukosa, manosa, dan galaktosa dengan struktur amorf. Hemiselulosa berfungsi menghubungkan antara lignin dan serat selulosa dan membuat jaringan antara selulosa, hemiselulosa, dan lignin menjadi lebih kaku. [6].

\section{c. Lignin}

Lignoselulosa adalah polimer yang amorf dengan berat molekul yang besar dan struktur yang kompleks. Lignoselulosa lebih tahan terhadap serangan jamur, bakteri, dan proses hidrolisis oleh asam [7]. Selulosa adalah penguat batang tanaman, lignoselulosa berfungsi melindungi selulosa dari kerusakan kimiawi dan biologis, sedangkan hemiselulosa adalah pengikat keduanyan [5].

Bahan-bahan dalam membuat kertas terdari dari 3 bagian, yaitu:

\section{a. Bahan Baku}

Bahan baku yang digunakan meliputi bahan baku yang dipakai dalam proses pembuatan kertas core ini merupakan waste kardus. Dimana bahan baku tersebut didapatkan dari supplier-supplier didekat pabrik. Ataupun supplier jauh yang 
memiliki ikatan yang erat dengan industri dalam perihal penyediaan bahan baku.

b. Bahan Pembantu

Ada 4 jenis yang digunakan dalam pembuatan kertas :

1) Air, diperlukan sebagai pelarut dan pencuci. Air sangat diperlukan dalam pembuatan kertas.

2) Bahan pemutih, diperlukan untuk membuat kertas putih bersih. Bahan pemutih tersebut yaitu:
a) Hidrogen peroksida (bleaching agerit) untuk memutihkan kertas
b) Natrium peroksida (swelling agerit)
c) Natrium bisufat (buffer) untuk menstabilkan $\mathrm{Ph}$

3) Bahan penghancur waste, diperlukan untuk menghancurkan waste dengan reaksi kimia. Bahan penghancur tersebut adalah:
a) Asam > Asam Sulfat
b) Alkali > Sodium Hidroksida

4) Bahan pewarna, diperlukan apabila hendak membuat kertas berwarna. Adalah: Pigmen, Acid Dyes, Basic Dyes, Direct Dyes.

c. Bahan pelengkap yang digunakan didalam industri kertas. Bahan-bahan tersebut adalah:

Bahan perekat, bahan untuk mengikat serat atau selulosa agar lebih kuat dan kokoh diantarannya:

- Chemical

- Perekat tepung tapioka

Selama tahun 2021, diperoleh hasil produksi 3 bahan dengan komposisi pembuatnya sebagai berikut.

Tabel 1. Data hasil komposisi produksi kertas

\begin{tabular}{|c|c|c|c|c|}
\hline \multirow{2}{*}{ Bahan Baku } & \multicolumn{4}{|c|}{ Produksi } \\
\cline { 2 - 5 } & \multicolumn{2}{|c|}{ MF } & BK & TL \\
\hline Marga lokal & $25 \%$ & $25 \%$ & $15 \%$ & $15 \%$ \\
\hline OMG/OIMG & $20 \%$ & $20 \%$ & $25 \%$ & $20 \%$ \\
\hline
\end{tabular}

Analisa Komposisi Bahan Penyusun Kertas Medium Fluting, Brown Kraft, dan Test Liner (Andhika Dwi Anggoro, Fatkur Rhohman) 


\begin{tabular}{|c|c|c|c|c|c|}
\hline \multicolumn{2}{|c|}{ SRPN } & $5 \%$ & $5 \%$ & & \\
\hline \multicolumn{2}{|c|}{ BBC putih } & $5 \%$ & $5 \%$ & $5 \%$ & $5 \%$ \\
\hline \multicolumn{2}{|c|}{ OCC short } & $25 \%$ & $25 \%$ & $35 \%$ & $40 \%$ \\
\hline \multirow{2}{*}{ OCC long } & OCC L & & & & \\
\cline { 2 - 6 } & BBC KCB & $20 \%$ & $20 \%$ & $20 \%$ & \\
\hline \multirow{2}{*}{ OCC VL } & VL & & & & \\
\cline { 2 - 6 } & KCB & & & & \\
\hline
\end{tabular}

Pada tabel 1 menunjukan data produksi pembuatan kertas medium fluting (MF), menggunakan campuran bahan baku berupa marga local (25\%), OMG (20\%), SRPN (5\%), BBC putih (5\%), OCC short (25\%), dan OCC long seperti BBC KCB (20\%) . Dari data produksi, pembuatan kertas brown kraft (BK) dan test liner (TL), untuk pembuatan kertas brown kraft (BK) menggunakan campuran bahan baku berupa marga local (15\%), OMG (25\%), BBC putih (5\%), OCC short (35\%), dan OCC long seperti BBC KCB (20\%), dan untuk pembuatan kertas test liner (TL) menggunakan campuran bahan baku berupa berupa marga local (15\%), OMG (20\%), BBC putih (5\%), OCC short (40\%), dan OCC long seperti BBC KCB (20\%).

OCC (Old Corrugated Container) adalah bahan yang mengandung potongan kertas karton. BBC (Box Board Cuttings) adalah bahan yang mengandung potongan/rajangan dari paperboard yang digunakan pada pembuatan folding paper cartons, box, dan jenis boxboard sejenis, banyak mengandung coating warna, total outthrows tidak lebih dari 2\%. OMG (Old Magazine Paper) adalah bahan yang mengandung lembaran majalah printed/unprinted clay coating. SRPN (Sorted residential papers \& news) Terdiri dari surat kabar yang telah disortir, surat, majalah, kertas cetak dan kertas tulis serta kertas lain yang dapat diterima yang dihasilkan dari program residensial (seperti koleksi rumah tangga dan apartemen residensial dan pusat pengantaran) yang disortir dan diproses di fasilitas daur ulang. Containerboard dan grade coklat (OCC, tas Kraft, boxboard dan papan pembawa Kraft) akan dianggap sebagai “Outthrows." Bahan Larangan tidak boleh melebihi 2\%. Outthrow tidak boleh melebihi 3\% [8] [9] [10]. 


\section{SIMPULAN}

Kertas merupakan bahan tipis yang dibuat dari serat-serat nabati pendek yang diendapkan serta dikeringkan. Umumnya dicampur dengan bahan-bahan tambahan lain dan atau bahan pewarna. Serat yang digunakan umumnya merupakan alami, serta memiliki selulosa dan hemiselulosa. Bahan-bahan pembuatan kertas terdiri dari 3 komponen ialah bahan baku, bahan pembantu dan bahan pelengkap. Sumber serat sangat menentukan terhadap perlakuan yang akan diberikan baik dari sisi proses dan target kertas yang akan kita buat. Semakin panjang serat, semakin tinggi kemungkinan serat untuk membantu daya kekuatan kertas (strenght properties). Panjang serat juga akan memperluas jangkauan ikatan antar serat. Jumlah kandungan selain serat yang terkandung dalam bahan baku, misal : plastik, pasir, batu, logam, coating, wax, sterofoam, wet streght, dsb. Semakin banyak kandungan kontaminan, maka beban proses untuk memisahkan dan membersihkan kontaminan semakin berat.

\section{DAFTAR PUSTAKA}

[1] L. H. Suryaningrum dan R. Samsudin, "POTENSI ENZIM SELULASE DALAM MENDEGRADASI MATERIAL LIGNOSELULOSA SEBAGAI BAHAN PAKAN IKAN," dalam Seminar Nasional Hasil Riset Pengolahan Produk dan Bioteknologi Kelautan dan Perikanan, Jakarta, 2018.

[2] Grinviro Biotekno Indonesia, "Pengolahan Limbah Industri Kertas (Pulp And Paper) Dengan Teknologi Dissolved Air Flotation (DAF)," 1911 n.d.. [Online]. Available: 2021.

[3] L. indriati dan N. Elyani, "EMPTY FRUIT BUNCHES AS PACKAGING PAPERS RAW MATERIAL," Konversi, Volume 7 No. 2., pp. 45-54, 2018.

[4] R. Brown, I.M.Saxena dan K. Kudlicka, "Cellulose Biosynthesis In Higher Plants," Trends Plant Sci, vol. 1, pp. 149-156, 1996.

[5] J. Lee, Biochemical Engineering, New Jersey: Prantica Hall, Englewood Cliffs, 1992.

[6] J. Bailey dan D. Ollis, Biochemical Engineering Fundamentals 2nd Ed., Singapore: Mcgraw-Hill International Edition, 1986.

[7] A. Widjaja, Aplikasi Bioteknologi Pada Industri Pulp dan Kertas, Surabaya: ITS Press, 2009. 
[8] VIPA Group, "Recovered Paper," VIPA Group, 2019. [Online]. Available: https://www.vipa.ch/recovered-paper/.

[9] C. J. Biermann, Handbook of Pulping and Papermaking second edition, California: Academic Press, 1996.

[10] H. Holik, Handbook of Paper and Board, Ravensburg: WILEY-VCH Verlag GmbH \& Co. KGaA, 2006. 